\title{
31
}

\section{The Religious Mission \\ of Sorrow}

It very often happens to us that to reach any notable result, either in life or in insight, is even thereby to introduce ourselves to a new problem. In the present state of the undertaking of these lectures such is our experience. The religious insight whose source is the loyal spirit was our topic in the foregoing lecture. If my own view is correct, this source is by far the most important that we have yet considered. It unites the spirit and the meaning of all the foregoing sources. Rightly interpreted, it points the way to a true salvation.

Yet the very last words of our sketch of the fruits of loyalty were of necessity grave words. Intending to show through what spirit man escapes from total failure, we were brought face to face with the tragedies which still beset the higher life. "Adversity"poor Griselda faced it in the tale. We left the loyal spirit appearing to us-as it does appear in its strongest representatives, able, somehow, in the power that is due to its insight, to triumph over fortune. But side by side with this suggestion of the nature of that which overcomes the world stood the inevitable reminder of the word: "In this world ye shall have tribulation."

How is tribulation related to religious insight? That is our present problem. It has been forced upon our attention by the study of the place and the meaning of loyalty. Some understanding of this prob-

[Reprinted from SRI, pp. 2 I3-54.] 
lem is necessary to any further comprehension of the lessons of all the foregoing sources of insight, and is of peculiar significance for any definition of the office of religion.

To nearly all of us, at some time in our lives, and to many of us at all times, the tragic aspect of human life seems to be a profound hindrance to religious insight of any stable sort. I must here first bring more fully to your minds why this is so-why the existence of tragedy in human existence appears to many moods, and to many people, destructive of faith in any religious truth and a barrier against rational assurance regarding the ultimate triumph of anything good. Then I want to devote the rest of this lecture to showing how sorrow, how the whole burden of human tribulation, has been, and reasonably may be, not merely a barrier in the way of insight, but also a source of religious insight. And this is the explanation of the title of the present lecture.

\section{I}

We approach our problem fully mindful of the limitations to which the purpose of these lectures confines us. The problem of evil has many metaphysical, theological, moral, and common-sense aspects upon which I can say nothing whatever in the present context. Human sorrow appears in our pathway in these lectures as a topic for us to consider, first, because whatever source of religious insight we have thus far consulted has shown us man struggling with some sort of ill, and, secondly, because there are aspects of this very struggle which will provide us with a new source of religious insight, and which will thus tend to throw new light upon the meaning of all the other sources. A thorough-going study of the problem of evil would require of us a complete philosophy not only of religion but of reality. But we are limiting ourselves, in these discussions, to a survey of certain sources.

The reasons why the existence and the prominence of evil in human life seem to all of us at some times, and to many of us at all times, a hindrance to the acceptance of any religious solution of the problems of life are familiar. I need then only to remind you what they are.

Without going into any subtleties regarding the definition of evil, it is obvious that our first characteristic reaction when we meet with what we take to be an evil is an effort to get rid of it, 
to shun its presence, or to remove it from existence. Pain, cold, burning heat, disease, starvation, death, our enemies, our dangers, these are facts that, precisely so far as we find them evil, we face with the determination to annul altogether their evil aspect.

A characteristic result of this tendency appears in the fact that man, who of all animals is most clearly aware of the presence of evil in his world, is for that very reason not only an ingenious deviser of new inventions for getting good things and for supplying his needs, but is also the most destructive of animals. He wars with his natural surroundings, and still more with his fellow-men, in ways that show how the instinctive aversions upon which his estimates of evil are founded are reinforced by the habits which he forms in his contests with ill fortune. Man the destroyer of evil thus appears, in much of his life, as a destroyer who is also largely moved by a love of destruction for its own sake. This love plays a great part in the formation of even very high levels of our social and moral consciousness. The heroes of song and story, and often of history as well, are fascinating partly, or chiefly, because they could kill and did so. We love victory over ill. Killing seems to involve such a victory. So we love killing, at least in the hero tales. The result is often a certain inconsistency. The gods offered Achilles the choice between a short life full of the glorious slaying of enemies and a long life of harmless obscurity. He chose the short life; and therefore he is to be remembered forever. For even when he would not fight, his "destructive wrath sent the souls of many valiant heroes to Hades, and left themselves a prey to the dogs and birds of the air." And when he returned to battle, what became of Hector? The song of the Nibelungs opens by assuring us that the old stories tell of many wonders, and of heroes worthy of praise (von Helden lobebaeren), and of great labours (von grosser Arebeit). These "great labours" consisted mainly in the slaying of other men. And this slaying was obviously "worthy of praise"; for it gave us a model for all our own struggle with evil. As for the heroes of history, of course, we love to dwell upon their constructive labours. But, after all, what sort of comparison is there in what the plain man, apart from a higher enlightenment, usually calls glory, between Washington and Napoleon? No doubt there will always be admirers of Napoleon who will think of him as a misunderstood reformer labouring for the building up of an ideal Europe. But even such admirers will join with the plain man in dwelling, with especial 
fascination, upon the Napoleon of Austerlitz. And they will not forget even Borodino. No doubt the lovers of Washington find him glorious. But where, in his career, belongs the glory of having put an end to the Holy Roman Empire, or of having destroyed the polity of the Europe of the old maps?

Man the destroyer thus glories in his prowess, and adores the heroes who were the ministers of death. And since, of course, his warfare is always directed against something that he takes to be an evil, the principle which directs his glorious conflicts seems to be one easy of general statement, inconsistent as some of the reasonings founded upon it seem to be. This principle is: "All evil ought to be destroyed. There ought to be none. It should be swept out of existence."

Of course, when the principle of the warfare with evil is thus abstractly stated, it does not tell us what we are to regard as an evil. It leaves the wise estimate of good and evil to be learned through a closer study of the facts of life. No doubt, then, Achilles, and the other heroes of song and story, may have become as glorious as they are by reason of our excessive love of destruction due to some imperfect estimate of the true values of life. And therefore the mere statement of the principle leaves open a very wide range for difference of opinion and for inconsistency of view as to what it is that ought to be destroyed. The natural estimate of the plain man, when he loves the heroes of old, seems to imply that one of the chief ills that man ought to destroy usually takes the form of some other man. And this way of estimating men in terms of their success in killing other men has its obvious inconsistencies. But, after all, as one may insist, much is gained when we have made up our minds as to what ought to be done with evil, whether evil is incorporated in our enemies, in our pains, or in our sins. We may leave to advancing civilization, or perhaps to some triumph of religion, the correction of our excessive fondness for the destruction of human life. What is essentially important is that it is part of man's mission to destroy evil. And about this general teaching the saints and the warriors, so it seems, may well agree.

Religion, it may be said, can have nothing to urge against this fundamental axiom. So far all appears clear. Evil ought to be driven out of the world. Common-sense says this. Every struggle with climate or with disease or with our foes is carried on in this spirit. The search for salvation is itself-so one may insist-simply another 
instance of this destructive conflict with impending ills. All that is most elemental in our hatreds thus agrees with whatever is loftiest in our souls, in facing evils with our "everlasting No." All the differences of moral opinion are mere differences as to what to destroy. Man is always the destroyer of ill.

\section{II}

But if you grant the general principle thus stated, the presence of evil in this world, in the forms that we all recognise, and in the degree of importance that it attains in all our lives, seems, indeed, a very serious hindrance in the way of religious insight. And the reason is plain. Religion, as we have said, in seeking salvation, seeks some form of communion with the master of life. That is, it seeks to come into touch with a power, a principle, or a mind, or a heart, that, on the one hand, possesses, or, with approval, surveys or controls the real nature of things, and that, on the other hand, welcomes us in our conflicts with evil, supports our efforts, and secures our success. I have made no effort, in these lectures, to define a theological creed. Such a creed forms a topic in which I take great interest but which lies beyond the limitations of this discourse. Yet our study of the historical relations between religion and morality, our earlier analysis of the religious need, have shown us that unless you are able to make some sort of effective appeal to principles that link you with the whole nature of things, your religious need must remain unsatisfied, and your last word will have to take, at best, the form of a moral, not a religious doctrine. Religion does not require us to solve all mysteries; but it does require for its stability some assurance that, so far as concerns our need of salvation, and despite the dangers that imperil our salvation, those that are with us, when we are rightly enlightened, are more than those that are against us.

In order to make this fact yet clearer, let us suppose that all such assurance is taken away from us. Review the result. Let it be supposed that we need salvation. Let it be granted that, as we naturally are, in our blindness and narrowness, and in the caprices of our passions, we cannot find the way out unless we can get into touch with some spiritual unity and reasonable life such as the loyal man's cause seems to reveal to him. Let it be further supposed, however, that all human causes are, in their way and time, as much subject 
to chance and to the capricious blows of fortune as we ourselves individually are. Let it be imagined that the cause of causes, the unity of the whole spiritual world, is, in fact, a mere dream. Let the insight of the reason and of the will, which, when taken in their unity, have been said by me to reveal to us that the universe is in its essence Spirit, and that the cause of the loyal is not only a reality, but the reality-let this insight, I say, be regarded as an illusion. Let no other spiritual view of reality prove probable. Then, indeed, we shall be left merely with ideals of life in our hands, but with no assurance that real life, in its wholeness, approves or furthers these ideals. Our need of salvation will then, to be sure, still remain. Our definition of what salvation would be if it should become ours will be unchanged. But, having thus abandoned as illusory or as uncertain all the sources of insight which I have so far been defending, we shall have upon our hands only the moral struggle for the good as our best resource. We shall then hope for no assurance of salvation. We shall abandon religion to the realm of mythical consolations, and shall face a grim world with only such moral courage as we can muster for the uncertain conflict. Our loyalty itself will lose its religious aspect. For the objective goodness of our cause-the divine grace which its presence seems to offer to our life-will no longer mean anything but a faint and uncertain hope, which we shall keep or not according to the caprices of our personal resolutions. Such, I say, would be the outcome of rejecting all sources of religious insight into the real nature of things.

The result, in the case now supposed, will be one which any honest man will indeed accept if he must, but which no one can regard as including any satisfactory religious insight whatever. I certainly do not here present these considerations as in themselves any arguments for religion, or as in themselves furnishing support for our previous arguments regarding the nature and the merits of the sources of insight which we have been reviewing. The case for which I have argued in the foregoing lectures must indeed stand or fall solely upon its own merits. And if the reason and the will, as the spirit of loyalty interprets and unifies their teachings, do not really show us any truth about the whole nature of things, I would not for a moment ask to have their teachings tolerated merely because, without such teachings, we should lose our grounds for holding to a religious interpretation of life. If we must fall back upon mere moral resoluteness, and abandon any assurance as to the re- 
ligious objects, and as to the way and the attainment of salvation, I, for one, am quite ready to accept the call of life, and to fight on for a good end so long as I can, without seeking for religious consolations that have once been shown to be mythical. But I have indicated to you, in general, my grounds for holding that our previous sources actually do give us an insight which is not only moral but religious, and do throw light upon our relations to a reason which moves in all things, to a divine will which expresses itself in all the universe, and to a genuine revelation of its purposes which this makes of itself when it inspires our loyalty. My present purpose is, not to reinforce these grounds by the mere threat that their rejection would involve an abandonment of any well-grounded religious assurance, but to present to you the fact that religion is, indeed, a search for a really divine foundation for the saving process.

Religion differs from morality in looking beyond our own active resoluteness for something-not ourselves-that gives a warrant, founded in the whole nature of things-a warrant for holding that this resoluteness will succeed and will bring us into union with that which saves.

Hence it is, indeed, true that if there is no master of life with whom we can come into touch, no triumph of the good in the universe, no real source of salvation-religion must result in disappointment. And then our only recourse must, indeed, be the moral will. This recourse is one that, as we have seen, many in our time are quite ready to accept. And such, in my own opinion, are for reasons that they do not themselves admit actually well on their way toward real salvation. Only it is useless to attribute to them, in their present stage of conviction, any conscious and assured possession of religious insight. To sum up, then, religion demands the presence of the master of life as a real being, and depends upon holding that the good triumphs.

But if we attempt to combine the two assertions, "All evil ought to be destroyed" and "In the universe as a whole the good triumphs," and hereupon to face the facts of human life as religion finds them, we are at once involved in familiar perplexities. With many of these perplexities the limitations of the present discussion, as already explained, forbid us to deal. I am merely trying to show, for the moment, why the presence of evil in our lives seems to be a hindrance in the way of religious insight. And it is enough if I emphasize at this point what must readily come to the consciousness of all of 
you when you consider the situation in which our whole argument seems now to have placed us.

The very existence of the religious need itself presupposes not only the presence, but the usual prevalence of very great evils in human life. For unless man is in great danger of missing the pearl of great price, he stands in no need of a saving process. A religious man may come to possess an acquired optimism-the hard-won result of the religious process which seems to him to have pointed out the way of salvation. But a man who begins with the assurance that all is ordinarily well with human nature is precluded from religion, in our sense of the word religion, by his very type of optimism. Such an optimist of the "first intention," such a believer that in the main it is well with human nature, can be, as we have seen, a moralist, although he is usually a very simple-minded moralist, as unaware of the graver moral problems as he is cheerfully indifferent to the hard case in which most of his brethren live. But whoever sees the deep need of human salvation, as the various cynics and rebels and sages and prophets whom we cited in our first lecture have seen it, has begun by recognising the bitterness of human loss and defeatthe gravity of the evil case of the natural man. Were not the world as it now is very evil, what, then, were the call for religion? Religion takes its origin in our sense of deep need-in other words, in our recognition that evil has a very real place in life. "Tempora pessima"-"The times are very evil"-is thus no phrase of a merely mediæval type of world-hatred. The woes of man are the presupposed basis of fact upon which the search for salvation rests.

And the further one goes in the pursuit of the sources of religious insight, the more, as we have ourselves found, does one's original recognition of the ill of the human world become both deepened and varied. From the solitude of one's individual sorrows one goes out to seek for religious relief in the social world, only to find how much more manifold the chaos of ordinary social life is than is the conflict of one's private passions. If one asks guidance from reason, reason appears at first as a sort of spirit brooding upon the face of the depths of unreason. When loyalty itself is created, it finds itself beset by adversities. If evil drives us to seek relief in religion, religion thus teaches us to know, better and better, the tragedy of life. Its first word is, thus, about evil and about the escape from evil. But its later words appear to have been a persistent discourse upon our tribulations. 
But how can religion, thus presupposing the presence of evil in our life, and illustrating this presence anew at every step, undertake to lead us to any assurance of the triumph of a good principle in the real world, in case, as seems so far obvious, such a triumph of a good principle would mean that all evil is to be simply destroyed and wiped out of existence?

Briefly restating the situation, it is this: If the evils of human life are indeed but transient and superficial incidents, or if-to use a well-known extreme form of statement-evil is an "unreality" altogether-then religion is superfluous. For there is no need of salvation unless man's ordinary case is, indeed, very really a hard case, that is, unless evil is a reality, and a deep-rooted one. But, on the other hand, if evil is thus deep-rooted in the very conditions of human life as they are, and if it persists upon higher levels even of the religious life, religion seems in danger of total failure. For unless goodness is somehow at the real heart of things-is, so to speak, the core of realitythe hope of salvation is a dream, and religion deceives us. But goodness, by the hypothesis that we are just now considering, requires that evil should be wholly abolished. How can that which should not exist at all, namely, evil, be in such wise the expression of the real nature of things that on the one hand religion is needed to save us from evil, and yet is able to do so only by bringing us to know that the real nature of things is good? Here is our problem. And it is a hard one.

In brief, as you may say, religion must take its choice. Either the evil in the world is of no great importance, and then religion is useless; or the need of salvation is great, and the way is straight and narrow; and then evil is deeply rooted in the very nature of reality, and religion seems a failure.

\section{III}

I believe that there is some advantage in stating in this somewhat crabbed and dialectical fashion, a problem which most of us usually but means to an end. Their end is to help us to a clear and rational sometimes tends to clear away the clouds with which emotion from approach through much more direct and pathetic experience. One advantage in crabbedness and in fondness for dialectic is that it moment to moment surrounds certain great problems of life. As I said earlier, in speaking of the office of the reason, abstract ideas are 
survey of the connections of things. When you are to examine the landscape from a height, in order to obtain a wide prospect, you may have to use a glass, or a compass, or some other instrument of abstraction, in order to define what the distance tends to render obscure, or what the manifoldness of the scenery surveyed makes it hard rightly to view in its true relations. And, in such cases, the glass or the compass is but an auxiliary, intended to help in the end your whole outlook. Now the world of good and evil is a world of wide prospects, of vast distances, of manifold features. A bit of dialectics, using abstract and one-sided considerations in succession, may prepare the way for seeing the whole better.

The plain man well knows the problem that I have just been characterising. He knows how it may enter his religious life. Only he does not usually think of it abstractly. It pierces his heart. Stunned by a grief, he may say: "I have trusted God, and now he forsakes me. How can a good God permit this horror in my life?" Yet the plain man, if religiously minded, also knows what is meant by saying, "Out of the depths have I cried." And he knows, too, that part of the preciousness of his very idea of God depends upon the fact that there are depths, and that out of them one can cry, and that God is precisely a being who somehow hears the cry from the depths. God, "pragmatically viewed," as some of our recent teachers express the matter, is thus often defined for the plain man's religious experience as a helper in trouble. Were there no trouble, there would be, then, it would seem, no cry of the soul for such a being, and very possibly no such being conceived by the soul that now cries. Yet this very God-one cries to him because he is supposed to be all-powerful, and to do all things well, and therefore to be a very present help in time of trouble. All this seems clear enough at the time when one is on the way up, out of the depths, or when one begins to praise God in the Psalmist's words, because, as one now says: "He hath planted my feet upon a rock, and hath established my goings." But how does all this seem at the moment when one suddenly falls into the pit of sorrow, and when one's eyes are turned downward; when he who doeth all things well permits the utmost treachery of fortune, and when the one who can hear every cry seems deaf to one's most heart-rending pleadings? The familiar explanation that all this is a penalty for one's sins may awaken an echo of Job's protest in the mind of the man who knows not how he has deserved this woe, or may arouse the deeper and now consciously 
dialectical comments on the mystery involved in the fact that God permits sin. "Why was I made thus blind and sinful?" one may cry. And hereupon religious insight becomes, indeed, confused enough, and may turn for relief to that well-known type of defiance which, if not religious, is at least moral; for it is a protest against evil. If at such moments God is, indeed, to our darkened vision, and, for us, who wait for his blessing, as if he were sleeping or on a journey, one can at least, as moral agent, utter this protest against ill, and wonder why his omnipotence does not make it effective. One thus begins, as it were, to try heroically to do the absent God's work for him.

All these are familiar experiences. They find us, too often, unprepared. They find us when emotion tends to cloud every insight. They illustrate a certain dialectical process which belongs to all human life and which plays its part in the whole history of religion. Perhaps it is well to state an aspect of this dialectical process abstractly, crabbedly, and unemotionally, as we have just done, in order that we may make ourselves the more ready to face the issue when life exemplifies it with crushing suddenness, and when

The painful ploughshare of passion

Grinds down to our uttermost rock.

The problem, as just abstractly stated, is this. Religion seems to face this dilemma: Either there are no great and essential ills about human life; and then there is no great danger of perdition, and no great need of salvation, and religion has no notable office; or there are great and essential ills, and man's life is in bitter need of salvation; but in that case evil is deeply rooted in the very nature of the reality from which we have sprung; and therefore religion has no right to assure us of communion with a real master of life who is able to do with evil what not only ought to be done with it, but ought always to have been done with it by any being able to offer man any genuine salvation. For (as we are assuming) what ought to be done, yes, what ought to have been done with evil from the beginning, is and was this: To banish it altogether from existence.

This, I say, is, when abstractly stated, the dilemma in which religion seems to be placed. Of this dilemma the countless struggles of the human soul when, in the spirit of some practical religion, it seeks for salvation and faces its woes are examples. These struggles are infinitely pathetic and in life are often confusing to insight. Is there any value in considering this abstract statement of the princi- 
ples upon which this dilemma seems to be founded? Possibly there is, if we can hereby be led also to consider-not indeed, in this place, the problems of theology, or the metaphysics of evil, but a new source of insight.

\section{IV}

This new source of insight begins to come to us when we observe, as we can often observe if we listen with closer attention to the voices of our own hearts, that the general principle, "Evil ought simply to be put out of existence," does not express our whole attitude toward all evils, and gives only an imperfect account either of our more commonplace and elemental or of our more elevated, heroic, and reasonable estimates of life.

The principle: "Evil ought to be simply abolished," is, indeed, one that we unquestionably apply, in our ordinary life, to a vast range of natural ills. But it is not universal. Let us first indicate its apparent range. Physical pain, when sufficiently violent, is an example of an ill that appears to us, in all its greater manifestations, plainly intolerable. So it seems to us to illustrate the principle that "Evil ought to be put out of existence." We desire, with regard to it, simply its abolition. The same is true of what one may call unassimilated griefs of all levels-the shocks of calamity at the moment when they first strike, the anguish of loss or of disappointment precisely when these things are new to us and appear to have no place in our life-plan. These are typical ills. And they all illustrate ills that seem to us to be worthy only of destruction. The magnitude of such ills as factors in the individual and in the social world often appears to us immeasurable. Pestilence, famine, the cruelties of oppressors, the wrecks of innocent human lives by cruel fortunesall these seem, for our ordinary estimates, facts that we can in no wise assimilate, justify, or reasonably comprehend. That is, we can see, in the single case, no reason why such events should form part of human life-except that so it indeed is. They seem, to our natural understanding, simply opaque data of experience, to be annulled or removed if we can. And to such ills, from our human point of view, the principle: "They ought to be simply driven out of existence," is naturally applied without limitation. The apparent range of this principle is therefore, indeed, very wide.

Now it forms no part of our present discourse to consider in detail 
the possible theological or metaphysical basis for a possible explanation of such ills. I have elsewhere written too much and too often about the problem of evil to be subject to the accusation of neglecting the pathos and the tragedy of these massive ills. This, however, I can at once say. In so far as ills appear to us thus, they are, indeed, no sources of religious insight. On the other hand, even when thus viewed, in all their blackness, they can be, and are, sources of moral enthusiasm and earnestness. Man the destroyer, when, awaking to the presence of such ills in his world, he contends with them, gets a perfectly definite moral content into his life. And he has his right to do so. Whatever his religion, he is morally authorised to labour against these unmediated evils with the heartiest intolerance. When such labour takes on social forms, it helps toward the loftiest humanity. The war with pain and disease and oppression, the effort to bind up wounds and to snatch souls from destruction-all these things constitute some of man's greatest opportunities for loyalty. Nevertheless, when man loyally wars with the ills such as physical anguish and pestilence and famine and oppression, he does not thereby tend to discover, through his own loyal act, why such individual ills are permitted in the world. In so far as these evils give him opportunity for service, they appeal to his loyalty as a warrior against them. If his cause includes, for him, activities that enter into this warfare with ills that are to be destroyed, these ills have thus indirectly conduced to his religious life. But it is his loyalty that in such cases is his source of religious insight. The ills themselves that he thus destructively fights remain to him as opaque as before. Why they find their place in the world he does not see. Now that they are found there, he knows what to do with them-namely, to annul them, to put them out of existence, as a part of his loyal service. But if he is religiously minded, he does not for a moment conceive that the ills with which he wars are there simply to give him the opportunity for his service. So far then it is, indeed, true that the ills which we have simply to destroy offer us no source of religious insight.

But now, as I must insist, not all the ills that we know are of this nature. Wide and deep and terrible as are those conflicts with the incomprehensible ills of fortune whose presence in the world we do not understand, there are other ills. And toward these other ills we take an attitude which is not wholly destructive. We find them, upon a closer view, inseparably bound up with good-so closely 
bound up therewith that we could not conceive a life wherein this sort of good which is here bound up with this sort of ill could be separated therefrom. In these cases the principle: "Evil should be simply put out of existence," proves to be a palpable falsity. As our knowledge of such ills grows clearer, we commonly find that there is, indeed, something about them, as they at any one moment appear to us, which ought, indeed, to be annulled, set aside, destroyed. But this annulling of one momentary or at least transient aspect of the ill is but part, in such cases, of a constructive process, which involves growth rather than destruction-a passage to a new life rather than a casting wholly out of life. Such ills we remove only in so far as we assimilate them, idealise them, take them up into the plan of our lives, give them meaning, set them in their place in the whole.

Now such ills, as I must insist, play a very great part in life and especially in the higher life. Our attitude toward them constitutes, above all, on the very highest levels of our reasonableness, a very great part of our attitude toward the whole problem of life. In the presence of these idealised evils, man the destroyer becomes transformed into man the creator. And he does so without in the least abandoning his justified moral distinctions, without indulging in any sort of "moral holiday," and without becoming unwilling to destroy when he cannot otherwise rationally face the facts before him than by destroying. He is not less strenuous in his dealing with his moral situation because he has discovered how to substitute growth for destruction and creative assimilation for barren hostility. $\mathrm{He}$ is all the more effectively loyal in the presence of such ills, because he sees how they can become, for his consciousness, parts of a good whole.

Ills of this sort may become, and in the better cases do become, sources of religious insight. Their presence in our world enables us the better to comprehend its spiritual unity. And because they are often very deep and tragic ills, which we face only with very deep and dear travail of spirit, they hint to us how, from the point of view of a world-embracing insight, the countless and terrible ills of the other sort, which we cannot now understand, and which, at present, appear to us merely as worthy of utter destruction, may still also have their places, as stages and phases of expression, in the larger life to which we belong. In our own power to assimilate and spiritualise our own ills, we can get at times a hint of such larger spiritual processes. In these very processes we also, through our 
loyal endeavour, can act our own real part; although what the larger processes are we cannot expect at present to comprehend better than a sympathising dog, whose master is devoting his life to furthering the highest spiritual welfare of a nation or of all mankind, can know why his master's face is now grief-stricken and now joyous.

In other words, the ills that we can spiritualise and idealise without merely destroying them hint to us that, despite the uncomprehended chaos of seemingly hopeless tragedy with which for our present view human life seems to be beset, the vision of the spiritual triumph of the good which reason and loyalty present to us need not be an illusion, but is perfectly consistent with the facts. The world is infinite. With our present view we could not expect to grasp directly the unity of its meaning. We have sources of insight which tend to our salvation by showing us, in general, although certainly not in detail, the nature of the spiritual process which, as these sources of insight persistently point out, constitutes the essence of reality. Whether these sources are themselves valid and trustworthy is a question to be considered upon its own merits. I have stated my case so far as our brief review requires it to be stated. I must leave to your own considerateness the further estimate of what these sources teach, both as to the reality of the master of life and as to the nature of the process of salvation. My present concern is simply with the cloud that the presence of evil seems to cause to pass over the face of all these sources. I cannot undertake wholly to dispel this cloud by showing you in detail why pestilences or why broken hearts are permitted to exist in this world. But I can show you that there are, indeed, ills, and very dark ills in life, which not only are there, but are essential to the highest life. I do not exaggerate our power to solve mysteries when I insist that these ills constitute not an opaque hindrance to insight, not a cloud over the sun of reason and of loyalty, but rather a source of insight. And, as I insist, they constitute such a source without being in the least an excuse for any indolence in our moral struggle with precisely those aspects of such ills as we ought to destroy. They show us how the triumph of the moral will over such adversities is perfectly consistent with the recognition that the most rational type of life demands the existence of just such adversities. Their presence in our world does not excuse sloth, does not justify a "moral holiday," does not permit us to enjoy any mere luxury of mystical contemplation of the triumph of the divine in the world, without ourselves taking our rational 
and strenuous part in the actual attainment of such triumph. But what these forms of ill show us is that there are accessible cases in which if-but only if-one does the divine will-one can know of the doctrine that teaches how the divine will can and does become perfect, not through the mere abolition of evil, but through suffering. Such cases of ill are true sources of insight. They reveal to us some of the deepest truths about what loyalty, and spiritual triumph, and the good really are. They make for salvation. They drive away clouds and bring us face to face with the will of the world.

I have so far spoken of evil in general. For the present purpose I need a name for the ills that one rationally faces only when one, through some essentially active, constructive, moral process, creatively assimilates and idealises them, and thus wins them over to be a part of good-not when one merely drives them out of existence. One name for such ills is Griselda's name: "Adversities." But I have chosen, in the title of this lecture, to use the vaguer untechnical name: Sorrow. A great physical pain, you in general cannot, at least at the moment, idealise. You then and there face it only as something intolerable, and can see no good except through its mere abolition. The same is true of any crushing blow of fortune, precisely in so far as it crushes. All such things you then and there view narrowly. Their mystery lies in the very fact that they are thus, for the moment, seen only narrowly. Hence, they are ipso facto hindrances tơ insight. But a sorrow-when you use the word you have already begun to assimilate and idealise the fact that you call a sorrow. That you have begun to idealise it, the very luxury of deep grief of ten vaguely hints, sometimes clearly shows. For sorrows may have already become tragically precious to you. Would you forget your lost love, or your dead, or your "days that are no more," even if you could? Is mere destruction, then, your only tendency in the presence of such sorrows. A closer view of your attitude toward such sorrows shows that they are not only clouding but revealing. They begin, they may endlessly continue, to show you the way into the spiritual realm and the nature of this realm.

By sorrow, then, I here mean an experience of ill which is not wholly an experience of that which as you then and there believe ought to be simply driven out of existence. The insight of which sorrow is the source, is an insight that tends to awaken within you a new view of what the spiritual realm is. This view is not in the least what some recent writers have blindly proclaimed it to be- 
a philosopher's artificial abstraction-a cruel effort to substitute a "soft" doctrine of the study for a moral and humane facing of the "hard" facts of human life. No, this view is the soul of the teaching of all the world's noblest and most practical guides to the most concrete living. This view faces hardness, it endures and overcomes. Poets, prophets, martyrs, sages, artists, the heroes of spirituality of every land and clime, have found in it comfort, resolution, and triumph. The philosopher, at best, can report what these have seen. And "soft," indeed, is the type of thoughtful effort which declines to follow with its ideas what all these have learned to express in their lives and in their religion.

\section{$\mathbf{V}$}

Because I am here not stating for you a merely speculative doctrine concerning the place of evil in a good and rational spiritual world, I once more need, at this point, to appeal as directly as I can to life. Let me present to you, from recent literature, a noteworthy instance of the use of our present source of insight. The instance is confessedly one where no complete and determinate religious creed is defended as the result of the use of the insight in question. And an actually eternal truth about the spiritual world-a very old truth in the lore of the wise, but a deeply needed truth for our own day -is illustrated by the instance which the tale portrays.

I refer to a recent short story, published in the Atlantic Montbly for November, I9 Io, and written by Cornelia A. P. Comer. It is entitled "The Preliminaries." It is, to my mind, an impressive union of a genuinely effective realism and a deep symbolism. The characters are very real human beings. Their problem is one of the most familiar problems of daily life-the problem as to the advisability of the proposed marriage of two young lovers. The conditions of the problem are hard facts, of a general type that is unfortunately frequent enough under our confusing modern conditions. These facts are viewed in the tale as such people might well view them. And yet the issues involved are, like all the problems of young lovers, issues that are bound up with all the interests of religion and with the whole problem of the reality of a spiritual world. These issues are treated as they truly are, with a result that is fairly supernatural in its ancient but always new appeal to a source of insight that we can reach only through sorrow.

Since the question inevitably concerns the prospects of the pro- 
posed marriage, the first statement of the problem is fully in harmony with the spirit of recent pragmatism. The truth of the assertion: "We ought to marry," is surely a truth that, as the pragmatists would say, the young lovers who make the assertion should regard as quite inseparable from the probable results to which this marriage will lead in concrete life. Such a truth then is, one would say, wholly empirical. A marriage proposal, to use the favourite phrase of pragmatism, is a "working hypothesis." Such hypotheses must be submitted to the test of experience. No such test, it would seem, would be absolute. What does poor humanity know as to the real values of our destiny? Meanwhile the whole problem of good and evil is in question. Marriage, especially under certain conditions, will lead to one or another sorrow. Can one face sorrow with any really deeper trust in life? Is life really a good at all, since there is so much sorrow in it? Must not any prudent person be afraid of life? Ought the lovers to defy fortune and to ignore obvious worldly prudence?

Such is the first statement of the problem. Its treatment in this admirable sketch shows an insight into the nature of good and evil which I had myself come to regard as very little present to the minds of the story-tellers of to-day, who are so often dominated by the recent love of power, by the tedious blindness of modern individualism, by false doctrines as to the merely temporal expediency of truth, and by the merely glittering show of unspiritual worldly efficiency. I rejoice to find that, in a literature which has been, of late, so devastated by a popularly trivial interpretation of pragmatism, and by an equally trivial disregard for the "rule of reason," there is still place for so straightforward and practical a recognition of eternal truth as the wise woman who has written this short story exemplifies.

The issue regarding this particular marriage proposal is stated at once in the opening words of the tale:

"Young Oliver Pickersgill was in love with Peter Lannithorne's daughter. Peter Lannithorne was serving a six-year term in the penitentiary for embezzlement."

The young hero is depicted as a high-minded youth of unquestionable and prosperous social position in his community. His beloved is a loyal daughter who is convinced that her father's crime was due solely to a momentary and benevolent weakness, and to a mind confused by care for the needs and too importunate requirements of his own family. Not unjustly attributing the father's final down- 
fall to the impatience, to the agonising discontent, and to the worldly ambition of her own mother, the daughter with spirit replies to the lover's proposal by saying plainly: "I will never marry any one who doesn't respect my father as I do." The lovers somewhat easily come to terms, at least apparently, as to this sole present ground for disagreement. The youth, not without inward difficulty, is ready to accept the daughter's version of her father's misadventure. In any case, love makes him indifferent to merely worldly scruples, and he has no fear of his own power to face his community as the loving husband of a convict's daughter; though there is, indeed, no doubt as to the father's actual guilt, and although Lannithorne is known to have admitted the justice of his sentence.

But to love, and to be magnanimously hopeful-this is not the same as to convince other people that such a marriage is prudent, or is likely, as the pragmatists would say, to have "expedient workings." Young Oliver has to persuade Ruth's mother on the one hand, his own father on the other, that such a marriage is reasonable. Both prove to be hard to convince. To the ordinary scruples of worldly prudence which young lovers generally have to answer, they easily add seemingly unanswerable objections. The motherthe convict's wife-now a brilliantly clear-witted but hopelessly narrow-minded invalid-a broken woman of the world-pragmatically enlightened, in a way, by the bitter experience of sorrow, but not in the least brought thereby to any deeper insight, faces the lover as an intruder upon her daughter's peace and her own desolation. She has known, she says, what the bitterness of an unhappy marriage can be and is. If she herself has had her share of blame for her husband's downfall, that only the more shows her such truth as, in this dark world, she still can grasp. "I do not want my daughters to marry"-this is, to her, the conclusion of the whole matter. The bitterness of her own marriage has taught her this lesson, which she expounds to the lover with all the passion of wounded pride and the dear-bought lore of life as she has learned it. But of course, as she admits, she may be wrong. Let the lover consult her husband at the jail. He-the convict-is a well-meaning man, after all. He fell; but he is not at heart a criminal. Let him say whether he wants his daughter to take up the burden of this new tragedy. So the mother concludes her parable.

The lover, baffled, but still hopeful, next turns to his own father for consent and encouragement. But now he has to listen to the 
teachings of a loftier yet to him profoundly discouraging prudence. Oliver's father is a truly high-minded man of the world, with a genuinely religious feeling in the background of his mind, and is intensely devoted to his son. But from this proposed match he recoils with a natural horror. The world is full of good girls. Why not choose one who brings no such sorrow with her? Peter Lannithorne was in his crime no worse, indeed, than many other men who are not in jail. He even meant on the whole well, and blundered, until at last from blunder he drifted into crime. He then took his penalty like a man, and owned that it was just. But, after all, he was found out. Such a taint lasts. It cannot be removed by repentance. The proposed marriage can only lead to misery. Peter Lannithorne himself, who, after all, "knows what's what," would be the first to admit this fact, if one asked his advice. If the son must persist in making light of a loving father's wisdom-well, let him then consult Peter Lannithorne himself. Ask the convict in his prison what a man needs and expects in the family of the woman whom he is to marry. This is the father's firm but kindly ultimatum.

Terrified by the gravity of repeated warnings, and dispirited by having to leave his dearest problem to the decision of the convict himself, Oliver determines to face the inevitable. He arranges for the interview at the jail, and is left by the warden alone with the prisoner in the prison library. Suddenly, as he faces his man, the youth finds himself in the presence of one who has somehow been transformed as if by a supernatural power. As for the convict's person-

His features were irregular and unnoticeable; but the sum-total of them gave the impression of force. It was a strong face, yet you could see that it had once been a weak one. It was a tremendously human face, a face like a battleground, scarred and seamed and lined with the stress of invisible conflicts. . . . Not a triumphant face at all, and yet there was peace in it. Somehow, the man had achieved something, arrived somewhere, and the record of the journey was piteous and terrible. Yet it drew the eyes in awe as much as in wonder, and in pity not at all.

Oliver, reassured by the new presence, and glad to find himself at last facing a man who has nothing left to fear in life, states as well as possible his main problem. The father of his beloved listens, first with surprise at the news, then with seriousness. Oliver finds himself forced to cut deep when he repeats his own father's appeal to know the convict's opinion about what a man expects to meet in his 
future wife's family, and then pauses with a keen sense of the cruelty of his own position. But Lannithorne, who has long since become accustomed to feeling the ploughshare of passion grind down to his uttermost rock, is perfectly ready with his response. As the youth pauses and then begins a new appeal-

The man looked up and held up an arresting hand. "Let me clear the way for you a little," he said. "It was a hard thing for you to come and seek me out in this place. I like your coming. Most young men would have refused, or come in a different spirit. I want you to understand that if in Ruth's eyes, and my wife's, and your father's, my counsel has value, it is because they think I see things as they are. And that means, first of all, that I know myself for a man who committed a crime and is paying the penalty. I am satisfied to be paying it. As I see justice, it is just. So, if I seem to wince at your necessary allusions to it, that is part of the price. I don't want you to feel that you are blundering or hurting me more than is necessary. You have got to lay the thing before me as it is."

Something in the words, in the dry, patient manner, in the endurance of the man's face, touched Oliver to the quick and made him feel all manner of new things: such as a sense of the moral poise of the universe, acquiescence in its retributions, and a curious pride, akin to Ruth's own, in a man who could meet him after this fashion, in this place.

Hereupon, fully aroused, the youth tells with freedom why the problem seems so hard for the young people, and how their elders all insist upon such frightful discouragements, and how much he longs to know the truth about life, and whether all such doubts and scruples as those of his own father and of Ruth's mother are well founded. At last the prisoner begins his reply:

"They haven't the point of view," he said. "It is life that is the great adventure. Not love, not marriage, not business. They are just chapters in the book. The main thing is to take the road fearlessly-to have courage to live one's life."

"Courage?"

Lannithorne nodded.

"That is the great word. Don't you see what ails your father's point of view, and my wife's? One wants absolute security in one way for Ruth; the other wants absolute security in another way for you. And security-why, it's just the one thing a human being can't have, the thing that's the damnation of him if he gets it! The reason it is so hard for a rich man to enter the Kingdom of Heaven is that he has that false sense of security. To demand it just disintegrates a man. I don't know why. It does."

Oliver shook his head uncertainly.

"I don't quite follow you, sir. Oughtn't one to try to be safe?" 
"One ought to try, yes. That is common prudence. But the point is that, whatever you do or get, you aren't after all secure. There is no such condition, and the harder you demand it, the more risk you run. So it is up to a man to take all reasonable precautions about his money, or his happiness, or his life, and trust the rest. What every man in the world is looking for is the sense of having the mastery over life. But I tell you, boy, there is only one thing that really gives it!"

"And that is_—?"

Lannithorne hesitated perceptibly. For the thing he was about to tell this undisciplined lad was his most precious possession; it was the price of wisdom for which he had paid with the years of his life. No man parts lightly with such knowledge.

"It comes," he said, with an effort, "with the knowledge of our power to endure. That's it. You are safe only when you can stand everytbing that can bappen to you. Then, and then only! Endurance is the measure of a man! . . . Sometimes I think it is harder to endure what we deserve, like me," said Lannithorne, "than what we don't. I was afraid, you see, afraid for my wife and all of them. Anyhow, take my word for it. Courage is security. There is no other kind."

Then-Ruth and I-_"

"Ruth is the core of my heart!" said Lannithorne thickly. "I would rather die than have her suffer more than she must. But she must take her chances like the rest. It is the law of things. If you know yourself fit for her, and feel reasonably sure you can take care of her, you have a right to trust the future. Myself, I believe there is some One to trust it to."

The speaker of this hard-won wisdom, after this appeal to the eternal, utters his last tremulous word as from a father's loving heart, and then the interview must end. The author concludes:

Finding his way out of the prison yard a few minutes later, Oliver looked, unseeing, at the high walls that soared against the blue spring sky. He could not realise them, there was such a sense of light, air, space, in his spirit.

Apparently, he was just where he had been an hour before, with all his battles still to fight, but really he knew they were already won, for his weapon had been forged and put in his hand. He left his boyhood behind him as he passed that stern threshold, for the last hour had made a man of him, and a prisoner had given him the master-key that opens every door.

\section{VI}

Now this, I insist, is insight. It is no "soft" doctrine. It is far beyond the sort of pragmatism that accepts the test of momentary results. 
As far as it goes, it is religious insight. It is insight, moreover, into the nature of certain ills which cannot, yes, which in principle, and even by omnipotence, could not, be simply removed from existence without abolishing the conditions which are logically necessary to the very highest good that we know. Life in the spirit simply presupposes the conditions that these ills exemplify.

What sorrow is deeper than the full recognition of one's own now irrevocable deed, if one has, hereupon, fully to confess that this deed is, from one's own present point of view, a crime? Yet how could such ills be simply removed from existence if any range of individual expression, of freedom, of power to choose is to be left open at all? How can one possess spiritual effectiveness-the privilege that youth most ardently demands-without assuming the risk involved in taking personal responsibility for some aspects of the lives of our fellows? As for our blunders, what more precious privilege do we all claim than the privilege of making our own blunders, or at least a due proportion of them? When we act, every act is done for eternity, since it is irrevocable. When we love, we ask the privilege to bind up other destinies with our own. The tragedies of such a world as ours are, therefore, not such as could be simply wiped out of existence, unless one were ready to deprive every individual personality both of its range of free choice and of its effectiveness of action. When we suffer, then, in such a world, we know indeed that there need have been no such suffering had there been no world at all. But precisely when our ills are most bound up with our own personal wills, we know that no mere removal of such ills could have occurred without the abolition of all the conditions which our spiritual freedom, our longing for effectiveness, and our love for union with other personalities make us regard as the conditions of the highest good. No God could conceivably give you the good of self-expression without granting you the privilege, not only of choosing wrongly, but of involving your brethren in the results of your misdeed. For when you love your kind, you aim to be a factor in their lives; and to deprive you of this privilege would be to insure your total failure. But if you possess this privilege, you share in a life that, in proportion to its importance and depth and range and richness of spiritual relations, is full of the possibilities of tragedy.

Face such tragedy, however, and what does it show you? The possibility, not of annulling an evil, or of ceasing to regret it, but 
of showing spiritual power, first, through idealising your grief, by seeing even through this grief the depth of the significance of our relations as individuals to one another, to our social order, and to the whole of life; secondly, through enduring your fortune; and thirdly, through conquering, by the might of the spirit, those goods which can only be won through such sorrow. What those goods are, the convict has just, if only in small part, told us. Griselda told us something about them which is much deeper still. For adversity and loyalty are, indeed, simply inseparable companions. There could not be loyalty in a world where the loyal being himself met no adversities that personally belonged to and entered his own inner life. That this is true, let every loyal experience bear witness.

Now such sorrows, such idealised evils, which are so interwoven with good that if the precious grief were wholly removed from existence, the courage, the fidelity, the spiritual self-possession, the peace through and in and beyond tribulation which such trials alone make possible, would also be removed-they surely show us that the abstract principle: "Evil ought to be abolished," is false. They show us that the divine will also must be made perfect through suffering. Since we can comprehend the meaning of such experiences only through resolute action, through courage, through loyalty, through the power of the spirit, they in no wise justify sloth, or mere passivity, or mystical idleness. The active dealing with such sorrow gives, as James himself once well asserts, a new dimension to life. No experiences go further than do these to show us how, in our loyalty and in our courage, we are becoming one with the master of life, who through sorrow overcomes.

Let man, the destroyer, then remember that there is one ill which he could not destroy, even if he were God, without also destroying all the spiritual prowess in which all those rejoice who, inspired by an ambition infinitely above that of Achilles, long to be one with God through bearing and overcoming the sorrows of a world.

We have thus indicated a source of insight. To tell more about what it reveals would at once lead me, as you see, close to the most vital of all Christian teachings, the doctrine of the Atonement. But such a study belongs elsewhere. 